\title{
Identifying Risks in Implementing Sustainable Building Materials in Condominium Fit-out Projects Using Analytic Hierarchy Process
}

\author{
Ereck R. Andal ${ }^{1, *}$, Joseph Berlin P. Juanzon ${ }^{2}$ \\ ${ }^{1}$ School of Graduate Studies, Mapúa University, Intramuros, Manila, 1002, Philippines \\ ${ }^{2}$ School of Civil, Environmental and Geological Engineering, Mapúa University, Intramuros, Manila, 1002, Philippines
}

Received September 17, 2020; Revised November 16, 2020; Accepted November 29, 2020

\section{Cite This Paper in the following Citation Styles}

(a): [1] Ereck R. Andal, Joseph Berlin P. Juanzon, "Identifying Risks in Implementing Sustainable Building Materials in Condominium Fit-out Projects Using Analytic Hierarchy Process," Civil Engineering and Architecture, Vol. 8, No. 6, pp. 1266 - 1276, 2020. DOI: 10.13189/cea.2020.080610.

(b): Ereck R. Andal, Joseph Berlin P. Juanzon (2020). Identifying Risks in Implementing Sustainable Building Materials in Condominium Fit-out Projects Using Analytic Hierarchy Process. Civil Engineering and Architecture, 8(6), 1266 1276. DOI: 10.13189/cea.2020.080610.

Copyright $\mathrm{O} 2020$ by authors, all rights reserved. Authors agree that this article remains permanently open access under the terms of the Creative Commons Attribution License 4.0 International License

\begin{abstract}
Regardless of achieving sustainability through building materials, there are always risks when implementing new techniques and methods. Since this research focused on condominium fit-out projects' utilization of sustainable materials, it will be useful if risks associated should be identified and analyzed first. The motivation for risk identification in this research focused on the environmental and economic dimensions of sustainability and risk criteria were identified through various literature reviews. The criteria include the following RC1-Adopting with the utilization of sustainable materials, RC2-Appropriate material selections and specifications, RC3-Availability of sustainable materials, RC4-Affordability of sustainable materials, RC5-Project delivery and schedule, and RC6-Scheme of a life-cycle. Prioritization of risk criteria was conducted by Analytic Hierarchy Process (AHP) with the ratings gathered from surveyed construction professionals. The data presented showed that a geometric mean (GM) of normalized principal eigenvector value made three (3) main criteria on top of the list. Namely, RC4 with GM $=14.89 \%$ at rank number 3; RC6 at rank number 2 with $\mathrm{GM}=16.22 \%$, and the criterion which garnered a unanimous ranking for all respondents at topmost priority is RC5 having a $\mathrm{GM}=38.77 \%$. The results obtained can be a guide in planning, navigating, and obtaining significant and favorable results in sustainable initiatives.
\end{abstract}

Keywords Sustainability, Fit-out Materials, Risk Identification, Risk Prioritization, AHP

\section{Introduction}

\subsection{The Background of the Study}

Historically, building construction contributes to a significant amount of environmental pollution, waste, and degradation. However, the construction industry proactively stood to minimize and resolve these issues by sustainable resource management which is one known key for environmental protection.

Being mentioned, sustainable development, a course composed of various techniques from planning, design, materials, methods, production, and processes, aims to protect the natural and built environment and humanity for the next generation. Hence, this concept has been established and continually seek improvement to satisfy the sustainable needs and viability of the construction industry through different concepts, one of which is sustainable materials.

As defined by Huberman and Pearlmutter [1] sustainable building materials are non-toxic, water, and energy-efficient, and recyclable. It also constitutes the 
maximization of the use of non-renewable resources by working in line with nature's cycles and inter-connections of ecosystems.

Regardless of achieving sustainability through building materials, there are always challenges when it comes to implementing sustainability principles. Wherein, achieving success for any project requires knowledge, expertise, and proper project management.

Indeed, being complex and diverse, construction projects are exposed to risks.

Movement for the construction companies in the application of risk management is commonly based on previous experiences. Formal risk analysis regarding time, management, and knowledge insufficiency is being deserted. And this singularity could increase employing sustainable building movement involvement.

Nowadays, sustainable practices demand every sector. Concurrently, different risks are rising along in the sustainable building construction process. This study, however, will concentrate on the identification phase of risks in applying various sustainable building materials in fit-out condominium projects thru the construction professional's point of view and assessment and review of related literature.

\subsection{Research Objective}

Two concepts involved in this study are construction risk and sustainability. Even though these two have different meanings, this study proposes to determine both sustainability and risk identically and then combining the two concepts. Simply, the research would like to clear and identify the correlations between the two when combined into one research goal.

Hence, the main objective of the research is to identify various risks in implementing sustainable building materials in condominium fit-out which will help to develop an understanding of different critical risk factors in projects.

More so, based on the research objective stated above, this study aims to address the following:

1. Identify risks associated with the use of sustainable building materials from different sustainable risk factor perspectives, economic and environmental.

2. Determine the construction professional's perception of risks accompanying sustainability.

3. Evaluate construction risks level based on sustainability risk criteria using the Analytic Hierarchy Process (AHP).
4. Develop a risk assessment system based on the standpoint of the utilization of sustainable building materials into condominium fit-out projects.

\subsection{Scope and Limitation}

The research will be set primarily in Taguig City, National Capital Region, Philippines, which is geographically situated in Metro Manila's southern portion. The location is chosen such that land development and conversion are emerging in the City.

Besides, sustainability risk identification that is anticipated in this study is however restricted to the number of construction professionals interviewed and project information's gathered thru related literature. Risk identification is done by ample review of best available studies which represents various sustainability risks; limited only to economic sustainability and environmental sustainability.

As one of the research goals is to establish an assessment of respondents' ratings by the Analytic Hierarchy Process, data gathered, therefore, will be utilized then analyzed through qualitative and quantitative research approaches. Both will be used to closely examine risk identification in the implementation of sustainable fit-out materials. Also, small sample size will be utilized to address the goals and objectives of this research for having limited resources and time being constraints.

Moreover, the risk assessment system will only reflect the results through data interpretation using the Analytic Hierarchy Process and aims to establish a guide for future researches implementing sustainability practices into different construction projects.

\section{Research Methodology}

Generally, as shown in Figure 1, the research style in this study includes: 1) Comprehensive reading and exploration of relevant literature, 2) Identify different risk factors from the sustainability dimensions; economic and environmental, 3) Construct survey questionnaires, 4) Selection of sustainability experts and construction professionals, 5) Perform Analytic Hierarchy Process for interpreting data gathered, 6) Identify risks in implementing sustainable building materials in condominium fit-out projects, and 7) Establish risk assessment system based on the identified sustainable risks in implementing sustainable building materials. 


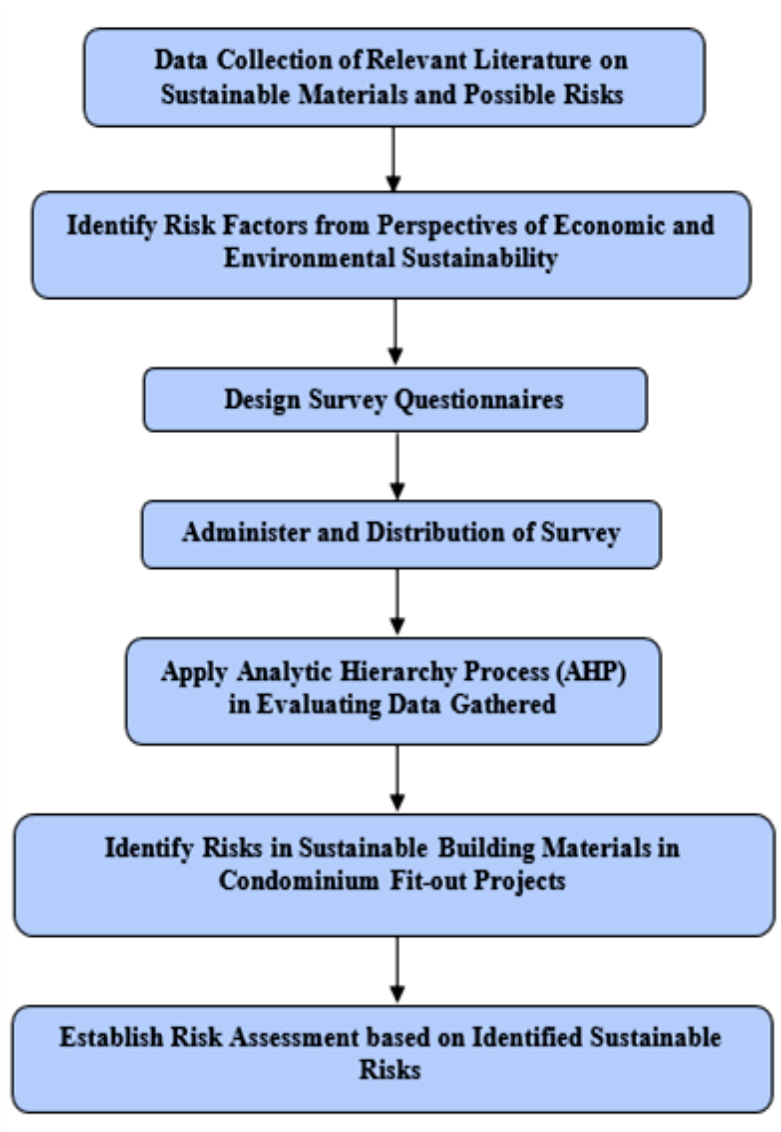

Figure 1. Conceptual Framework

\subsection{Research Design}

Both qualitative and quantitative data and analysis will be used in this research study.

\subsection{Research Setting}

With spikes in the demand for residential properties, this study will be strategically set to one of the promising land development projects in Taguig City, Metro Manila, Philippines, the McKinley West, a 34.5-hectare ultra-high-end township development in Fort Bonifacio beside Forbes Park and Manila Polo Club [2].

McKinley West will develop luxury private bequests with some properties having their cutting-edge security highlights and first-of-its-kind luxury comforts. The ultra-high-end residential condominium is bringing urban living to a new level by incorporating smart home technology. Upbringing sustainability and viable modern design to its residential condominium projects, make this a suitable research setting for this study. Hence through this study, the Philippine construction industry will be conventionally assessed its current and lessons-learned experiences with regards to identifying risks in sustainable initiatives.

\subsection{Respondents Selection}

The research method gives a clear view of whom the data will be gathered from. And since expert's views will be vital in data analysis, the selection of participants will be coming from construction professionals, who have engaged and gained experiences in sustainable building construction. Moreover, the project team in-charge who has direct involvement in sustainable construction and risk management, this could be Project Managers, Sustainability Managers and/or Risk Managers, Site Engineers, Quantity Surveyors and/or Cost Engineers, Site Architects, Planning Engineers, Quality Control Engineer, Safety Engineer, Risk Analysts and others who have direct involvement to sustainable risk management, are to be surveyed to have concrete data needed in line with the objectives of this study. By these means, the selection of various sustainable professionals who practice in the Philippines can be identified and will narrow possible sampling.

Hence, shown in Table 1 are the respondents' information and qualifications wherein the researcher purposively selected them to be part of this research study. Five respondents are tapped to participate and rank the risk categories according to the statistical tool used. Their project management expertise and experiences will be the core of the statistical tabulation and results. By this means, prioritization among the categories solely reflects the depth of expert's knowledge, experiences and understanding about the topic.

\subsection{Data Gathering Style \& Sampling Process}

The research will focus on the explorative approach of study wherein information and data gathering will primarily start broad and narrows down during the analysis.

As Saunders [3] described, explorative research has three major methods specifically 1 ) conducting literature research, 2) interviewing experts, and 3) conducting a survey through a questionnaire. All three methods will be applied in this study for the purpose to answer its main goals.

Research participants are to be identified as Construction Professionals who are selected and approached purposively for this study.

Simultaneously, data gathered will undergo a statistical investigation that will help to identify significant risks involving sustainable building construction. In particular, generalization will be provided by the analysis of the results of the Analytic Hierarchy Process or AHP. 
Table 1. Respondents Information and Qualifications

\begin{tabular}{|c|c|c|c|c|c|}
\hline \multirow{2}{*}{ INFORMATION } & \multicolumn{5}{|c|}{ RESPONDENT (R) } \\
\hline & $\mathrm{R} 1$ & $\mathrm{R} 2$ & R3 & $\mathrm{R} 4$ & R5 \\
\hline $\begin{array}{l}\text { (a)PROFESSIONAL } \\
\text { SPECIALIZATION }\end{array}$ & $\begin{array}{c}\text {-Fit-out } \\
\text { Construction } \\
\text {-Project } \\
\text { Management }\end{array}$ & $\begin{array}{c}\text { - Project } \\
\text { Management } \\
\text { - Building Interior } \\
\text { Fit-out and } \\
\text { Engineering } \\
\text { Upgrades } \\
\end{array}$ & $\begin{array}{c}\text {-Project } \\
\text { Management } \\
\text {-Construction } \\
\text { Management } \\
\text {-Reg. Master } \\
\text { Plumber } \\
\end{array}$ & $\begin{array}{l}\text {-Project } \\
\text { Management and } \\
\text { Construction } \\
\text { Engineering }\end{array}$ & $\begin{array}{c}\text {-Project } \\
\text { Management } \\
\text {-Construction } \\
\text { Management }\end{array}$ \\
\hline $\begin{array}{c}\text { (b)JOB POSITION } \\
\text { (Current) }\end{array}$ & $\begin{array}{c}\text { Senior Project } \\
\text { Manager }\end{array}$ & Project Manager & Project Manager & Project Manager & $\begin{array}{l}\text { Assistant Project } \\
\text { Manager }\end{array}$ \\
\hline $\begin{array}{l}\text { (c)YEARS OF WORK } \\
\text { EXPERIENCE }\end{array}$ & 17 & 16 & 12 & 11 & 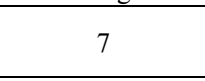 \\
\hline $\begin{array}{l}\text { (d)CERTIFICATIONS } \\
\text { AND AFFILIATIONS }\end{array}$ & $\mathrm{n} / \mathrm{a}$ & $\begin{array}{c}\text {-Acred.Safety } \\
\text { Professional } \\
\text {-Acred.Pollution } \\
\text { Control Professional }\end{array}$ & $\begin{array}{c}\text {-Materials Engr I } \\
\text {-Master's Degree } \\
\text { (MEM-CM) }\end{array}$ & $\begin{array}{c}\text {-ISO Quality, } \\
\text { Environmental } \\
\text { \&Occupational } \\
\text { Health, and Safety - } \\
\text { Auditor } \\
\end{array}$ & $\mathrm{n} / \mathrm{a}$ \\
\hline $\begin{array}{l}\text { (e)EXPERIENCED IN } \\
\text { RESIDENTIAL } \\
\text { BUILDING PROJECTS } \\
\end{array}$ & $\checkmark$ & $\checkmark$ & $\checkmark$ & $\checkmark$ & $\checkmark$ \\
\hline $\begin{array}{c}\text { (f)ENGAGED IN } \\
\text { CONDOMINIUM } \\
\text { FIT-OUT PROJECTS }\end{array}$ & $\checkmark$ & $\checkmark$ & $\checkmark$ & $\checkmark$ & $\checkmark$ \\
\hline $\begin{array}{c}\text { (g)WORKED IN } \\
\text { SUSTAINABLE OR } \\
\text { GREEN PROJECTS } \\
\end{array}$ & $\checkmark$ & $\checkmark$ & $\checkmark$ & $\checkmark$ & $\checkmark$ \\
\hline $\begin{array}{c}\text { (h)RISK AWARENESS IN } \\
\text { SUSTAINABLE } \\
\text { CONSTRUCTION } \\
\end{array}$ & $x$ & $\checkmark$ & $\checkmark$ & $\checkmark$ & $\checkmark$ \\
\hline
\end{tabular}

\subsection{Statistical Tool: Analytic Hierarchy Process}

A statistical tool namely, the Analytic Hierarchy Process (AHP) has been widely studied and used with various research after its development by Sir Thomas L. Saaty[4] in 1970.

More so, AHP is a decision-aiding method which aims to quantify relative priorities for a given set of alternatives on a ratio scale, based on the judgment of the decision-maker, and stresses the importance of the instinctive judgments of a decision-maker as well as the consistency of the comparison of alternatives in the decision-making process [4].

As one of the objectives of this paper, the application of the AHP in risk identification for implementing sustainable building materials in condominium fit-out projects will be presented.

Hence, step-by-step methods applying AHP into the research are as follows:

1. Determine the focus problems or research goals.

2. Organize the topics, firstly by the main objective or goal of the study followed by the major criteria of problems to be identified and lastly the sub-criteria which detailed the set of alternatives.

3. Construct a set of pair-wise comparison matrices for each of the lower levels with one matrix for each element in the level immediately above by using the relative scale measurement shown in Table 2. The pair-wise comparisons are done in terms of which element dominates the other.
Table 2. AHP Pair-wise Comparison Scale

\begin{tabular}{|c|c|}
\hline NUMERICAL RATING & EXPERT JUDGMENTS \\
\hline 9 & Extremely \\
\hline 8 & Very strongly to extremely \\
\hline 7 & Very strongly \\
\hline 6 & Strongly to very strongly \\
\hline 5 & Strongly \\
\hline 4 & Moderately to strongly \\
\hline 3 & Moderately \\
\hline 2 & Equally to moderately \\
\hline 1 & Equally \\
\hline &
\end{tabular}

4. There is $n(n-1) /$ judgments required to develop the set of matrices in step 3. Reciprocals are automatically assigned in each pair-wise comparison.

5. Hierarchical synthesis is now used to weigh the eigenvectors (priority vector) by the weights of the criteria and the sum is taken over all weighted eigenvector entries corresponding to those in the next lower level of the hierarchy.

6. Having made all the pair-wise comparisons, the consistency is determined by using the eigenvalue, $\lambda \max$, to calculate the consistency index, $\mathrm{CI}$ as follows:

$$
\mathbf{C I}=\frac{(\lambda \max -n)}{(n-1)}
$$

where $n$ is the matrix size. Judgment consistency can be checked by taking the consistency ratio (CR) of CI with the appropriate value in Table 3 . The $\mathrm{CR}$ is acceptable if it 
does not exceed 0.10. If it is more, the judgment matrix is inconsistent. To obtain a consistent matrix, judgments should be reviewed and improved.

7. Steps 3-6 are performed for all levels in the hierarchy.
Following the procedures, this study aims to develop a risk assessment system and to identify risks associated with implementing sustainable building materials in condominium fit-out projects, which is the main goal of this research.

Table 3. Average Random Consistency Ratio (CR)

\begin{tabular}{|c|c|}
\hline SIZE OF MATRIX & RANDOM CONSISTENCY \\
\hline 10 & 1.49 \\
\hline 9 & 1.45 \\
\hline 8 & 1.41 \\
\hline 7 & 1.32 \\
\hline 6 & 1.24 \\
\hline 5 & 1.12 \\
\hline 3 & 0.9 \\
\hline 2 & 0.58 \\
\hline 1 & 0 \\
\hline
\end{tabular}

Table 4. Identified Risk Criteria

\begin{tabular}{|c|c|}
\hline MAIN CRITERIA & SUB-CRITERIA \\
\hline \multirow{5}{*}{$\begin{array}{l}\text { Adopting with the } \\
\text { Utilization of Sustainable } \\
\text { Materials } \\
\text { (RC1) }\end{array}$} & Lack of adequate information regarding the materials and products $[5,6]$. \\
\hline & The absence of regulations and codes that encourage the use of sustainable material $[7,8]$. \\
\hline & Lack of financial incentives due to the current financial constraints [9]. \\
\hline & Sustainability measure is not considered by stakeholders $[8,10,11]$. \\
\hline & Fear of long pay-back period $[8,12]$. \\
\hline \multirow{5}{*}{$\begin{array}{l}\text { Appropriate Material } \\
\text { Selections \& } \\
\text { Specifications } \\
\text { (RC2) }\end{array}$} & Difficulty of providing special materials for sustainability (cost, availability, maintenance) [10]. \\
\hline & Plentiful, impractical, and inconsistent methods, standards, and guidelines [10]. \\
\hline & Overestimation of the capital cost of energy-efficient measures proposed by cost consultants [13-17]. \\
\hline & $\begin{array}{l}\text { Inability to express the requirements quantitatively and address methods that enable comparisons, quality } \\
\text { assurance, and monitoring [18-20]. }\end{array}$ \\
\hline & $\begin{array}{c}\text { "Greenwashing". The green label of some products is used for marketing reasons more than for the } \\
\text { environmental conditions of these products }[9,21] .\end{array}$ \\
\hline \multirow{5}{*}{$\begin{array}{c}\text { Availability of } \\
\text { Sustainable Materials } \\
\text { (RC3) }\end{array}$} & $\begin{array}{l}\text { Imported \& limited products. The inability to source locally produced environmentally responsible products } \\
{[7,21] .}\end{array}$ \\
\hline & Lack of environmentally sustainable materials $[8]$. \\
\hline & $\begin{array}{l}\text { Lack of trusted materials suppliers. The reliability of information from product suppliers and manufacturers } \\
{[7,21] .}\end{array}$ \\
\hline & Lack of statutory requirements that cover sustainable procurement [22]. \\
\hline & Time to source materials $[23]$. \\
\hline \multirow{5}{*}{$\begin{array}{c}\text { Affordability of } \\
\text { Sustainable Materials } \\
\text { (RC4) }\end{array}$} & Sustainability may lead to an increase in construction costs, in the short term [9]. \\
\hline & High initial cost incurred in purchasing sustainable materials [13-17]. \\
\hline & Lack of funding, restrictions on expenditure, and reluctance to incur a higher capital cost [24]. \\
\hline & A reluctance on the part of funders to adopt innovative technologies [9]. \\
\hline & Cost of sustainable materials is still uncertain [25]. \\
\hline \multirow{5}{*}{$\begin{array}{l}\text { Project Delivery and } \\
\text { Schedule } \\
\text { (RC5) }\end{array}$} & Decelerated construction speed to fulfill the added sustainability requirements [10]. \\
\hline & $\begin{array}{l}\text { Difficulty of determining within the limited time available, the most suitable sustainable materials } \\
\qquad[19,21,26,27] .\end{array}$ \\
\hline & $\begin{array}{c}\text { Specifying of sustainable materials will often take place a year or more before the actual purchase and } \\
\text { procurement of the materials [25]. }\end{array}$ \\
\hline & The idea that the use of environmentally friendly materials may increase the duration of the project [7]. \\
\hline & Time available to identify and evaluate alternative, its method, and quality [25]. \\
\hline \multirow{5}{*}{$\begin{array}{l}\text { Scheme of a Life Cycle } \\
\text { (RC6) }\end{array}$} & $\begin{array}{l}\text { A large number of natural materials are available in limited quantities and recover very slowly the energy } \\
\text { consumed during their life cycle [28]. }\end{array}$ \\
\hline & Ignorance of life cycle cost, the concept of cradle to grave $[8,12]$ \\
\hline & The lack of sufficient awareness to deal with these materials during the occupancy and maintenance period [7] \\
\hline & $\begin{array}{l}\text { Lack of adequate data on the potential environmental impacts of materials used provided through their life } \\
\text { cycle [7]. }\end{array}$ \\
\hline & $\begin{array}{c}\text { Determination of embodied energy, the energy necessary to obtain, process, manufacture, transport, install, } \\
\text { maintain, demolish, and dispose of the material }[7,21,28] .\end{array}$ \\
\hline
\end{tabular}




\section{Results and Discussion}

\subsection{Identified Risks}

Based on the major risks identified through collective data gathering and literature review, the results of the risk identification in implementing sustainable building materials in condominium fit-out projects categorized only six (6) major criteria concerning sustainable risk perspectives, economic and environmental, and presented in Table 4. The main Risk Criterion (RC) identified includes Adopting with the Utilization of Sustainable Materials (RC1), Appropriate Material Selections \& Specifications (RC2), Availability of Sustainable Materials (RC3), Affordability of Sustainable Materials (RC4), Project Delivery and Schedule (RC5) and Scheme of a Life Cycle (RC6). Whereas, five (5) sub-criteria were recognized to support each main criterion. More so RC1, $\mathrm{RC} 2$ and $\mathrm{RC} 3$ fall with an environmental perspective while RC4, RC5, and RC6 are with an economic perspective of sustainability.

\subsection{Statistical Interpretation: AHP Risk Tabulation}

Consolidating the completed research survey, a pairwise comparison matrix was developed for each respondent's rating (see Appendix). From this comparison matrix, the weights for each compared element or criterion were calculated.

Then, the rating consistency was identified. This rating is the resulted value of the consistency ratio or C.R which can be calculated from AHP parameters like the
Eigenvalue, consistency index, and random index.

Using the data generated, a summarized consistency indicator was developed to identify which rating has or have not consistent as presented in Table 5 .

As presented in Table 5, consistency rating from all respondents was considerably inconsistent wherein all values exceed Saaty's criteria or limit that C.R should be less than 0.10 or in $10 \%$ [4].

Hence, if the resulting C.R is not consistent, the pairwise comparison is repeated. However, it is neglected for this study in particular to preserve the initial value of the ratings and the time of study being constrained.

So, continuing the AHP calculations, the prioritization weights were tabulated in Table 6 . The data presented showed that a geometric mean (GM) of normalized principal eigenvector value made three (3) main criteria on top of the list. Namely, RC4-Affordability of Sustainable Materials with $\mathrm{GM}=14.89 \%$ at rank number 3; RC6-Scheme of a Life Cycle at rank number 2 with $\mathrm{GM}=16.22 \%$, and the criterion which garnered a unanimous ranking for all respondents at topmost priority is RC5-Project Delivery and Schedule having a $\mathrm{GM}=38.77 \%$.

Other criteria fall on a lower prioritization value includes RC3-Availability of Sustainable Materials, RC2-Appropriate Material Selections \& Specifications, and RC1-Adopting with the Utilization of Sustainable Materials and with the resulting GM of $14.66 \%, 7.57 \%$, and $3.14 \%$, respectively. The values of the GM correspond to the resulting weights of the rate from the five (5) respondents on the given criterion comparison.

Table 5. Summarized Consistency Indicator

\begin{tabular}{|c|c|c|c|c|c|}
\hline PARAMETERS & \multicolumn{5}{|c|}{ RESPONDENT (R) } \\
\hline$n=6$ (no. of criteria) & $R 1$ & $R 2$ & $R 3$ & $R 4$ & $R 5$ \\
\hline Eigen Value ( $\lambda$ max) & 7.0120 & 9.2935 & 7.9627 & 8.2283 & 9.1993 \\
\hline Consistency Index (C.I) & 0.2025 & 0.6587 & 0.3925 & 0.4456 & 0.6398 \\
\hline Random Index (R.I) & 1.24 & 1.24 & 1.24 & 1.24 & 1.24 \\
\hline Consistency Ratio (C.R, \%) & $16.33 \%$ & $53.12 \%$ & $31.66 \%$ & $35.94 \%$ & $51.60 \%$ \\
\hline Consistent? & $\mathrm{X}$ & $\mathrm{X}$ & $\mathrm{X}$ & $\mathrm{X}$ & $\mathrm{X}$ \\
\hline
\end{tabular}

Table 6. Summarized Prioritization Weights and Ranking

\begin{tabular}{|c|c|c|c|c|c|c|c|}
\hline \multirow{3}{*}{$\begin{array}{l}\text { RISK CRITERIA } \\
\text { (RC) }\end{array}$} & \multicolumn{5}{|c|}{$\begin{array}{l}\text { NORMALIZED PRINCIPAL EIGENVECTOR } \\
\text { (PRIORITY WEIGHTS) }\end{array}$} & \multirow{3}{*}{$\begin{array}{c}\text { GEOMETRIC } \\
\text { MEAN } \\
(\mathrm{GM})\end{array}$} & \multirow{3}{*}{ RANK } \\
\hline & \multicolumn{5}{|c|}{ RESPONDENT (R) } & & \\
\hline & $\mathrm{R} 1$ & $\mathrm{R} 2$ & R3 & R4 & R5 & & \\
\hline $\mathrm{RC} 1$ & $3.14 \%$ & $3.42 \%$ & $3.16 \%$ & $3.10 \%$ & $2.89 \%$ & $3.14 \%$ & 6 \\
\hline $\mathrm{RC} 2$ & $3.32 \%$ & $12.55 \%$ & $9.54 \%$ & $8.99 \%$ & $6.94 \%$ & $7.57 \%$ & 5 \\
\hline $\mathrm{RC} 3$ & $14.47 \%$ & $12.27 \%$ & $18.75 \%$ & $10.92 \%$ & $18.65 \%$ & $14.66 \%$ & 4 \\
\hline $\mathrm{RC} 4$ & $23.07 \%$ & $14.12 \%$ & $5.06 \%$ & $16.39 \%$ & $27.10 \%$ & $14.89 \%$ & 3 \\
\hline $\mathrm{RC} 5$ & $32.94 \%$ & $39.49 \%$ & $42.07 \%$ & $51.03 \%$ & $31.35 \%$ & $38.77 \%$ & 1 \\
\hline RC6 & $23.07 \%$ & $18.16 \%$ & $21.41 \%$ & $9.58 \%$ & $13.08 \%$ & $16.22 \%$ & 2 \\
\hline
\end{tabular}




\section{Conclusion}

The motive of risk identification is to find, understand, and describe risks that would assist or prevent a project team and stakeholders in accomplishing its objectives. Relevant, appropriate, and up-to-date statistics are vital in identifying risks. That's why a multi-decision-making tool, namely the Analytic Hierarchy Process, is utilized in this research to determine the risks associated with implementing sustainable building materials in condominium fit-out projects.

Thus, experts' prioritization on compared criterion, as presented in Table 4, became the main data needed in calculating the consistency ratio thru pair-wise comparison, as summarized in Table 5, and the priority weights, as ranked in Table 6. The determination of these data is used to support the validity and weight of the accuracy of the resulting prioritization of identified risks.

The analysis then showed and identified that RC5-Project delivery and schedule is the criterion that the respondents believed to be at the highest risk priority when implementing sustainable materials. It is assumed that the project timeline may adjust to fulfill the added requirements, to specify suitable materials, and to evaluate their method and quality before the actual purchase and procurement happen.
Hence, RC5 is followed by RC6-Scheme of a life-cycle and RC4-Affordability of sustainable materials at the second and third priority levels, respectively. All of this is categorized to be on economic sustainability preferences. And that consideration on cost and financing sustainable materials might be crucial. But assuming that stakeholders agreed to allocate budget on sustainability initiatives, some may still question the longevity and the life-cycle cost of each material. And besides, the cost of sustainable materials is still uncertain.

It is worth mentioning also, the rest of the risk criteria identified, which are all under environmental sustainability perspectives, namely RC3-Availability of sustainable materials, RC2-Appropriate material selections and specifications, and RC1-Adopting to sustainable building materials. The importance of identifying all six (6) criteria showed how prioritization in risk project management is relevant in dealing with this kind of initiative.

Another output of this research is establishing a risk assessment framework with relevance to the implementation of sustainability and this being said, illustrated in Figure 2 is the suggested risk assessment framework. This system is divided into three phases to develop a clearer evaluation and study of what is needed to achieve. Hence, each phase is described in Table 7.

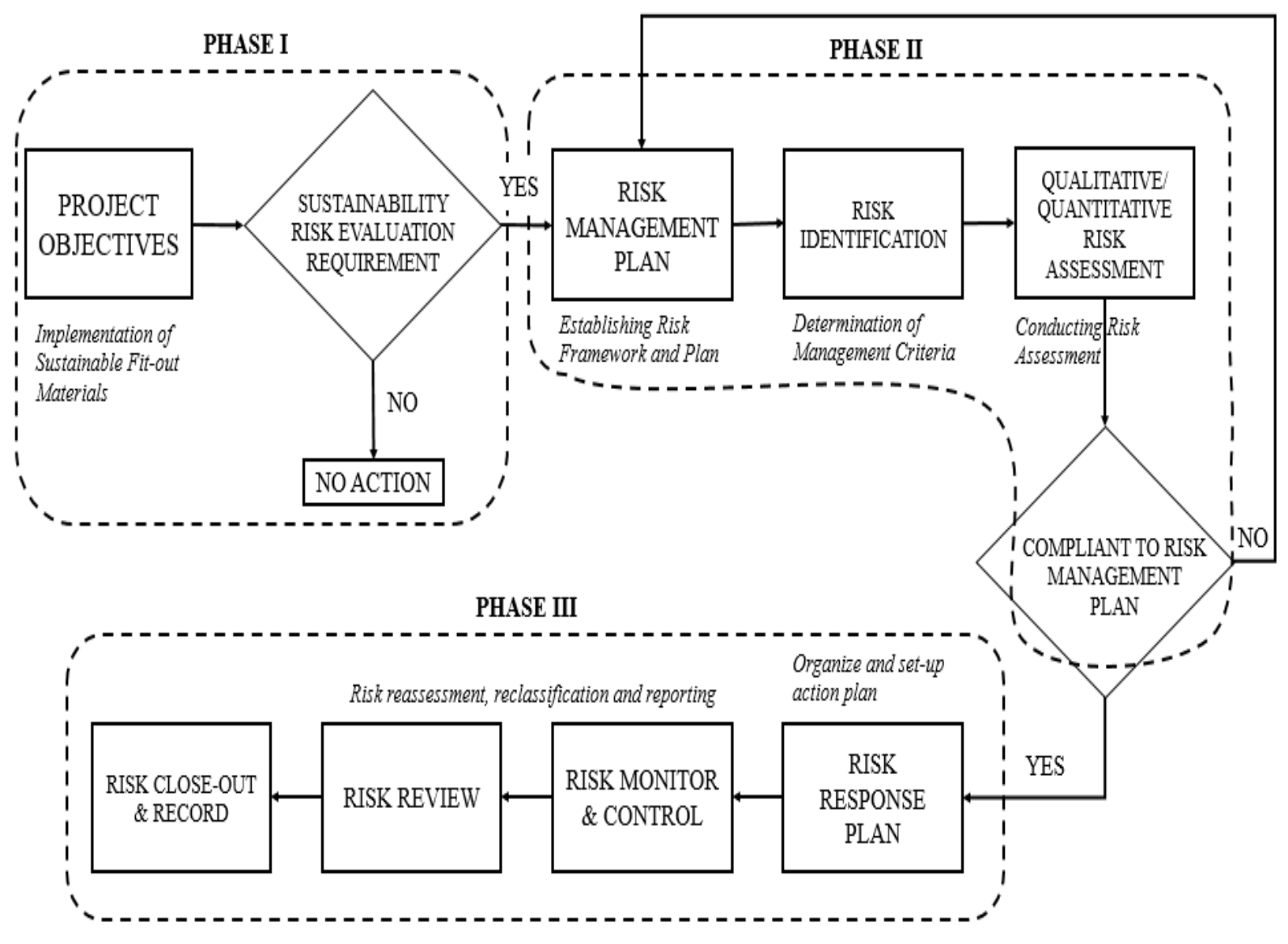

Figure 2. Sustainability Risk Assessment System 
Table 7. Description of Risk Assessment Stages

\begin{tabular}{|c|c|c|}
\hline \multicolumn{2}{|r|}{ STAGES } & RELATED STEPS UNDERTAKEN \\
\hline I & $\begin{array}{l}\text { Objective Formulation and } \\
\text { Scoping }\end{array}$ & $\begin{array}{ll}\cdot & \text { Identification of project particulars } \\
& \text { Defining objectives } \\
\text { - } & \text { Determining stakeholders' concern } \\
\text { - } & \text { Sustainability screening evaluation } \\
& \text { Scoping and options identification } \\
\end{array}$ \\
\hline II & $\begin{array}{c}\text { Planning and Conducting Risk } \\
\text { Assessment }\end{array}$ & $\begin{array}{ll} & \text { Identifying sustainability indicator and metrics selection } \\
\text { - } & \text { Identifying risk sources and categories } \\
\text { - } & \text { Attributes of assessments necessary to characterize risks } \\
\text { - } & \text { Determining the appropriate level of uncertainty and variability analysis } \\
\text { - } & \text { Analysis of probability risk occurrence, impact, and exposure }\end{array}$ \\
\hline III & Risk Management & $\begin{array}{ll} & \text { Risk reduction and an action plan } \\
- & \text { Identifying new risks and planning for them } \\
\text { - } & \text { Keeping track of existing risks } \\
\text { - } & \text { Reassessment and reclassification of risks if necessary } \\
\text { - } & \text { Risks monitoring, controlling and review } \\
\end{array}$ \\
\hline
\end{tabular}

The suggested system will provide a schematic view of how sustainability risk management would be helpful in a given project management requirement. By forming the framework, it may not only use to evaluate possible risks but to be able to conduct a thorough understanding of the application of sustainable initiatives to a project.

As the study emphasized risk identification to be acknowledged significantly similar to other project management processes, it can be indispensable, and neglecting its importance might lead to unwanted challenges. Thereby, appropriate prioritization among identified risks will be helpful to transform challenges into opportunities. Likewise, the resulting prioritization leveling and identified risks from this study can be useful to stakeholders who might initiate economic ventures and environmental developments. More so, the project team must be aware and should identify associated risks, whether or not their resources are beneath its control. While part of this study is the listing and identification of risk that recognized the top three criteria, the project team must not neglect and should consider all six identified sustainability risks because there can be greater than one form of outcome, which may result in series of tangible or intangible consequences.

As for this study, being project delivery and schedule on the top risk priority, the project team must set a program that will systematize the timeline and schedule of the project while considering sustainable initiatives. Construction is now changing its traditional practices into a greener one that is why crucial study and proper implementation of sustainable materials in condominium fit-out projects must also be studied.

Yet environmental and economic fit-out materials, for instance, are projected to be the key tool in sustainable initiatives and still facing concerns and risks when applied to a project. So, better understanding and identification could be a start to plan, differentiate, and manage possible risks.

\section{Acknowledgements}

It is my honor and sincere appreciation to acknowledge all the people who contributed to the success and fulfillment of this study and foremost the Almighty for the wisdom and grace.

\section{APPENDIX}

\section{Respondents Resulting AHP Data}

\section{Respondent 1 (R1)}

\section{Pairwise Comparison Matrix}

Tabulation of the respondent's decision ratings in each criterion comparison.

\begin{tabular}{|c|c|c|c|c|c|c||}
\hline R1 & RC1 & RC2 & RC3 & RC4 & RC5 & RC6 \\
\hline RC1 & 1 & 1 & $1 / 9$ & $1 / 5$ & $1 / 7$ & $1 / 5$ \\
\hline RC2 & 1 & 1 & $1 / 5$ & $1 / 5$ & $1 / 7$ & $1 / 5$ \\
\hline RC3 & 9 & 5 & 1 & $1 / 5$ & 1 & $1 / 5$ \\
\hline RC4 & 5 & 5 & 5 & 1 & $1 / 3$ & 1 \\
\hline RC5 & 7 & 7 & 1 & 3 & 1 & 3 \\
\hline RC6 & 5 & 5 & 5 & 1 & $1 / 3$ & 1 \\
\hline & & & \multicolumn{3}{|c|}{$\begin{array}{c}\text { Eigen Value }(\lambda)=7.012 \\
\text { itector sol'n }=8\end{array}$} \\
\cline { 5 - 8 } & & & \multicolumn{3}{|c|}{ delta $(\Delta)=9.9 \mathrm{E}-8$} \\
\hline
\end{tabular}




\section{Criteria Weight and Ranking}

Presented below are the priority weights and ranking of each criterion.

\begin{tabular}{|c|c|c|c|c|}
\hline R1 & PRIORITY & RANK & $(+)$ & $(-)$ \\
\hline RC1 & $3.14 \%$ & 6 & $1.00 \%$ & $1.00 \%$ \\
\hline RC2 & $3.32 \%$ & 5 & $0.70 \%$ & $0.70 \%$ \\
\hline RC3 & $14.47 \%$ & 4 & $10.10 \%$ & $10.10 \%$ \\
\hline RC4 & $23.07 \%$ & 2 & $9.40 \%$ & $19.40 \%$ \\
\hline RC5 & $32.94 \%$ & 1 & $21.00 \%$ & $21.00 \%$ \\
\hline RC6 & $23.07 \%$ & 2 & $19.40 \%$ & $19.40 \%$ \\
\hline & \multicolumn{3}{|c|}{ Consistency Index (CI) } & 0.2025 \\
\hline & \multicolumn{3}{|c|}{ Random Index (RI) } & 1.24 \\
\hline & \multicolumn{3}{|c|}{ Consistency Ratio (CR, \%) } & $16.33 \%$ \\
\hline
\end{tabular}

\section{Respondent 2 (R2)}

\section{Pairwise Comparison Matrix}

Tabulation of the respondent's decision ratings in each criterion comparison.

\begin{tabular}{|c|c|c|c|c|c|c|}
\hline $\mathrm{R} 2$ & $\mathrm{RC} 1$ & $\mathrm{RC} 2$ & $\mathrm{RC} 3$ & $\mathrm{RC} 4$ & $\mathrm{RC} 5$ & RC6 \\
\hline $\mathrm{RC} 1$ & 1 & $1 / 5$ & $1 / 5$ & 1 & $1 / 7$ & $1 / 5$ \\
\hline $\mathrm{RC} 2$ & 5 & 1 & 5 & 1 & $1 / 5$ & $1 / 5$ \\
\hline $\mathrm{RC} 3$ & 5 & $1 / 5$ & 1 & 5 & $1 / 5$ & $1 / 5$ \\
\hline $\mathrm{RC} 4$ & 1 & 1 & $1 / 5$ & 1 & $1 / 5$ & 5 \\
\hline RC5 & 7 & 5 & 5 & 5 & 1 & 6 \\
\hline RC6 & 5 & 5 & 5 & $1 / 5$ & $1 / 6$ & 1 \\
\hline & & & & \multicolumn{3}{|c|}{ Eigen Value $(\lambda)=9.29356$} \\
\hline & & & & \multicolumn{3}{|c|}{$\begin{array}{c}\text { Eigen Vector sol'n }=13 \\
\text { iterations }\end{array}$} \\
\hline & & & & \multicolumn{3}{|c|}{$\operatorname{delta}(\Delta)=5.4 \mathrm{E}-8$} \\
\hline
\end{tabular}

\section{Criteria Weight and Ranking}

Presented below are the priority weights and ranking of each criterion.

\begin{tabular}{|c|c|c|c|c|}
\hline R2 & PRIORITY & RANK & $(+)$ & $(-)$ \\
\hline RC1 & $3.42 \%$ & 6 & $2.90 \%$ & $2.90 \%$ \\
\hline RC2 & $12.55 \%$ & 4 & $13.60 \%$ & $13.60 \%$ \\
\hline RC3 & $12.27 \%$ & 5 & $16.70 \%$ & $16.70 \%$ \\
\hline RC4 & $14.12 \%$ & 3 & $22.00 \%$ & $22.00 \%$ \\
\hline RC5 & $39.49 \%$ & 1 & $18.80 \%$ & $18.80 \%$ \\
\hline RC6 & $18.16 \%$ & 2 & $17.40 \%$ & $17.40 \%$ \\
\hline \hline \multicolumn{6}{|c|}{ Random Index (RI) } & 1.24 \\
\hline
\end{tabular}

\section{Respondent 3 (R3)}

\section{Pairwise Comparison Matrix}

Tabulation of the respondent's decision ratings in each criterion comparison.

\begin{tabular}{|c|c|c|c|c|c|c|}
\hline R3 & $\mathrm{RC} 1$ & $\mathrm{RC} 2$ & RC3 & $\mathrm{RC} 4$ & RC5 & RC6 \\
\hline $\mathrm{RC} 1$ & 1 & 1 & $1 / 7$ & $1 / 7$ & $1 / 7$ & $1 / 7$ \\
\hline $\mathrm{RC} 2$ & 1 & 1 & 1 & 7 & $1 / 7$ & $1 / 7$ \\
\hline $\mathrm{RC} 3$ & 7 & 1 & 1 & 7 & 1 & 1 \\
\hline $\mathrm{RC} 4$ & 7 & $1 / 7$ & $1 / 7$ & 1 & $1 / 7$ & $1 / 7$ \\
\hline RC5 & 7 & 7 & 1 & 7 & 1 & 7 \\
\hline RC6 & 7 & 7 & 1 & 7 & $1 / 7$ & 1 \\
\hline & & & & \multicolumn{3}{|c|}{ Eigen Value $(\lambda)=7.96277$} \\
\hline & & & & \multicolumn{3}{|c|}{$\begin{array}{c}\text { Eigen Vector sol'n }=10 \\
\text { iterations }\end{array}$} \\
\hline & & & & \multicolumn{3}{|c|}{$\operatorname{delta}(\Delta)=1.2 \mathrm{E}-8$} \\
\hline
\end{tabular}

\section{Criteria Weight and Ranking}

Presented below are the priority weights and ranking of each criterion.

\begin{tabular}{|c|c|c|c|c|}
\hline R3 & PRIORITY & RANK & $(+)$ & $(-)$ \\
\hline RC1 & $3.16 \%$ & 6 & $2.30 \%$ & $2.30 \%$ \\
\hline RC2 & $9.54 \%$ & 4 & $9.50 \%$ & $9.50 \%$ \\
\hline RC3 & $18.75 \%$ & 3 & $8.90 \%$ & $8.90 \%$ \\
\hline RC4 & $5.06 \%$ & 5 & $5.80 \%$ & $5.80 \%$ \\
\hline RC5 & $42.07 \%$ & 1 & $37.00 \%$ & $37.00 \%$ \\
\hline RC6 & $21.41 \%$ & 2 & $15.80 \%$ & $15.80 \%$ \\
\hline \multicolumn{4}{|c|}{ Consistency Index (CI) } & 0.392555 \\
\hline & \multicolumn{3}{|c|}{ Random Index (RI) } & 1.24 \\
\hline & \multicolumn{3}{|c|}{ Consistency Ratio (CR, \%) } & $31.66 \%$ \\
\hline
\end{tabular}

\section{Respondent 4 (R4)}

\section{Pairwise Comparison Matrix}

Tabulation of the respondent's decision ratings in each criterion comparison.

\begin{tabular}{|c|c|c|c|c|c|c|}
\hline R4 & $\mathrm{RC} 1$ & $\mathrm{RC} 2$ & $\mathrm{RC} 3$ & $\mathrm{RC} 4$ & $\mathrm{RC} 5$ & $\mathrm{RC} 6$ \\
\hline $\mathrm{RC} 1$ & 1 & 1 & $1 / 5$ & $1 / 7$ & $1 / 9$ & $1 / 3$ \\
\hline $\mathrm{RC} 2$ & 1 & 1 & $1 / 5$ & $1 / 3$ & 1 & $1 / 3$ \\
\hline $\mathrm{RC} 3$ & 5 & 5 & 1 & $1 / 5$ & $1 / 9$ & 1 \\
\hline RC4 & 7 & 3 & 5 & 1 & $1 / 9$ & 1 \\
\hline RC5 & 9 & 1 & 9 & 9 & 1 & 9 \\
\hline RC6 & 3 & 3 & 1 & 1 & $1 / 9$ & 1 \\
\hline & & & & \multicolumn{3}{|c|}{ Eigen Value $(\lambda)=8.22839$} \\
\hline & & & & \multicolumn{3}{|c|}{$\begin{array}{c}\text { Eigen Vector sol'n }=11 \\
\text { iterations }\end{array}$} \\
\hline & & & & \multicolumn{3}{|c|}{$\operatorname{delta}(\Delta)=1.8 \mathrm{E}-8$} \\
\hline
\end{tabular}




\section{Criteria Weight and Ranking}

Presented below are the priority weights and ranking of each criterion.

\begin{tabular}{|c|c|c|c|c|}
\hline $\mathbf{R} 4$ & PRIORITY & RANK & $(+)$ & $(-)$ \\
\hline RC1 & $3.10 \%$ & 6 & $1.90 \%$ & $1.90 \%$ \\
\hline RC2 & $8.99 \%$ & 5 & $13.90 \%$ & $13.90 \%$ \\
\hline RC3 & $10.92 \%$ & 3 & $11.10 \%$ & $11.10 \%$ \\
\hline RC4 & $16.39 \%$ & 2 & $12.80 \%$ & $12.80 \%$ \\
\hline RC5 & $51.03 \%$ & 1 & $37.10 \%$ & $37.10 \%$ \\
\hline RC6 & $9.58 \%$ & 4 & $5.60 \%$ & $5.60 \%$ \\
\hline \multicolumn{4}{|c|}{\begin{tabular}{l|l} 
& Consistency Index $(\mathrm{CI})$
\end{tabular}} & 0.445679 \\
\hline & \multicolumn{3}{|c|}{ Random Index (RI) } & 1.24 \\
\hline & \multicolumn{3}{|c|}{ Consis tency Ratio (CR, \%) } & $35.94 \%$ \\
\hline
\end{tabular}

\section{Respondent 5 (R5)}

\section{Pairwise Comparison Matrix}

Tabulation of the respondent's decision ratings in each criterion comparison.

\begin{tabular}{|c|c|c|c|c|c|c|}
\hline R5 & $\mathrm{RC} 1$ & $\mathrm{RC} 2$ & $\mathrm{RC} 3$ & $\mathrm{RC} 4$ & RC5 & RC6 \\
\hline $\mathrm{RC} 1$ & 1 & $1 / 3$ & $1 / 7$ & $1 / 7$ & $1 / 3$ & $1 / 3$ \\
\hline $\mathrm{RC} 2$ & 3 & 1 & $1 / 3$ & $1 / 5$ & $1 / 3$ & 2 \\
\hline $\mathrm{RC} 3$ & 7 & 3 & 1 & 3 & $1 / 7$ & 2 \\
\hline $\mathrm{RC} 4$ & 7 & 5 & $1 / 3$ & 1 & 5 & $1 / 3$ \\
\hline $\mathrm{RC} 5$ & 3 & 3 & 7 & $1 / 5$ & 1 & 7 \\
\hline RC6 & 3 & $1 / 2$ & $1 / 2$ & 3 & $1 / 7$ & 1 \\
\hline & & & & \multicolumn{3}{|c|}{ Eigen Value $(\lambda)=9.19933$} \\
\hline & & & & \multicolumn{3}{|c|}{$\begin{array}{c}\text { Eigen Vector sol'n }=13 \\
\text { iterations }\end{array}$} \\
\hline & & & & \multicolumn{3}{|c|}{$\operatorname{delta}(\Delta)=1.7 \mathrm{E}-8$} \\
\hline
\end{tabular}

\section{Criteria Weight and Ranking}

Presented below are the priority weights and ranking of each criterion.

\begin{tabular}{|c|c|c|c|c|}
\hline R5 & PRIORITY & RANK & $(+)$ & $(-)$ \\
\hline RC1 & $2.89 \%$ & 6 & $2.00 \%$ & $2.00 \%$ \\
\hline RC2 & $6.94 \%$ & 5 & $5.10 \%$ & $5.10 \%$ \\
\hline RC3 & $18.65 \%$ & 3 & $17.50 \%$ & $17.50 \%$ \\
\hline RC4 & $27.10 \%$ & 2 & $37.60 \%$ & $37.60 \%$ \\
\hline RC5 & $31.35 \%$ & 1 & $33.40 \%$ & $33.40 \%$ \\
\hline RC6 & $13.08 \%$ & 4 & $19.70 \%$ & $19.70 \%$ \\
\hline & \multicolumn{3}{|c|}{\begin{tabular}{l|l} 
& Consistency Index (CI)
\end{tabular}} & 0.639866 \\
\hline & \multicolumn{3}{|c|}{ Random Index (RI) } & 1.24 \\
\hline & \multicolumn{3}{|c|}{ Consistency Ratio (CR, \%) } & $51.60 \%$ \\
\hline
\end{tabular}

\section{REFERENCES}

[1] N. Huberman, D. Pearlmutter. A Life Cycle Energy Analysis of Building Materials in the Negev Desert, Energy Build Vol.40, 837-848, 2008.

[2] Mckinley West: Live Exceptionally, Online available from https://www.mckinleywest.com

[3] M. N. Saunders. Research Methods for Business Students, 5/e: Pearson Education, India, 2011.

[4] T.L. Saaty. The Analytic Hierarchy Process, McGraw-Hill: New York, 1980.

[5] C. Stieg. The Sustainability Gap, Journal of Interior Design 32 (1): 6-21, 2006.

[6] C. Griffin, C. Knowles, C. Theodoropoulos, J.H. Allen. Barriers to the Implementation of Sustainable Structural Materials in Green Buildings, Structures and Architecture Proceedings of the 1 st International Conference on Structures and Architecture, ICSA 1349-1357, 2010.

[7] A.H. Mohsin, D.S. Ellk. Identifying Barriers to the Use of Sustainable Building Materials in Building Construction, Journal of Engineering and Sustainable Development, 22, 107-115, 2018.

[8] D. Aghimien, C. Aigbavboa, A. Oke, C. Musenga. Barriers to Sustainable Construction Practices in the Zambian Construction Industry, International Conference on Industrial Engineering and Operations Management, Paris, France, 2018.

[9] A. Enshassi, P.E. Mayer. Barriers to the Application of Sustainable Construction Concepts in Palestine, World Sustainable Building Conference. Tokyo, Japan, 2005.

[10] M. Tafazzoli. Accelerating the Green Movement: Major Barriers to Sustainable Construction, 54th Associated Schools of Construction Annual International Conference, 315-319, 2018.

[11] S. Studer, R. Welford, P. Hills. Drivers and Barriers to Engaging Small and Medium-sized Companies in Voluntary Environmental Initiatives, The Centre of Urban Planning and Environmental Management, The University of Hong Kong, 2005.

[12] O. Ametepey, C. Aigbavboa, K. Ansah. Barriers to Successful Implementation of Sustainable Construction in the Ghanaian Construction Industry, International Journal on Applied Human Factors and Ergonomics, Vol.3, 5-7, 2015.

[13] P.T.I. Lam, E.H.W. Chan, C.K. Chau, C.S. Poon, K.P. Chun. Integrating Green Specifications in Construction and Overcoming Barriers in Their Use, Journal of Professional Issues in Engineering Education and Practice, 135 (4): 142$52,2009$.

[14] E. Bartlett, N. Howard. Informing the Decision-makers on the Cost and Value of Green Building, Building Research \& Information 28 (5-6): 315-24, 2000.

[15] J. Ayarkwa, A. Acheampong, F. Wiafe, B.E. Boaten. Factors Affecting the Implementation of Sustainable Construction in Ghana: The Architect's Perspective. 6th International Conference on Infrastructure Development in Africa, 12- 14, Kumasi, Ghana, 2017.

[16] M.M. Reham, M. Eldin (2017). Sustainable Interior Design for Homes, Indian Journal of Science and Technology 10 (15): 1-9, 2017. 
[17] Y.H. Ahn, A.R. Pearce, Y. Wang, G. Wang. Drivers and Barriers of Sustainable Design and Construction: The Perception of Green Building Experience, International Journal of Sustainable Building Technology and Urban Development 4 (1): 35-45, 2013.

[18] J.M. Franz. Attitudes Towards Sustainability and Their Implication for Education, Practice and Future Research, In Forum II: Architectural Education for the 3rd Millennium, Queensland University of Technology, Australia, 453-60, 1998.

[19] T. Häkkinen, K. Belloni. Barriers and Drivers for Sustainable Building, Building Research \& Information 39 (3): 239-55, 2011.

[20] A. Templeton, A. Perceptions of Practicing Interior Designers: Motivations that Encourage their Sustainable Design Practices. Ph.D. diss., Colorado State University, Libraries, 2011.

[21] M. Hankinson, A. Breytenbach. Barriers that Impact on the Implementation of Sustainable Design, Cumulus Conference: Northern World Mandate, Helsinki, Finland, Aalto University, 1-11, 2013.

[22] A. Banaitis. Sustainable Construction Industry in Cambodia: Awareness, Drivers and Barriers, International Journal for
Sustainability, 4-6, 2018.

[23] D. Guerin, D. Ginthner. Designers Knowledge of Green Design: What do we do now? IDEC International Conference Abstract, 50-51, 1999.

[24] A. Sourani, M. Sohail. Barriers to Addressing Sustainable Construction in Public Procurement Strategies, Proceedings of the ICE - Engineering Sustainability, 164, 2011.

[25] E. Lee, A. Allen, B. Kim. Interior Design Practitioner Motivations for Specifying Sustainable Materials: Applying the Theory of Planned Behavior to Residential Design, Journal of Interior Design 38 (4): 1-16, 2013.

[26] K. Williams, C. Dair. What is stopping sustainable building in England? Barriers Experienced by Stakeholders in Delivering Sustainable Developments, Sustainable Development 15 (3): 135-47, 2007.

[27] L. Bacon. Interior Designer's Attitudes Toward Sustainable Interior Design Practices and Barriers Encountered when Using Sustainable Interior Design Practices, MSc diss., University of Nebraska, 2011.

[28] S. Moxon, Sustainability in Interior Design, Laurence King Publishing, London, 2012. 